\title{
The Role Motivation to Overcome Fossilization in Pandemic Era
}

\author{
Asmul Hayati \\ Universitas Negeri Padang \\ email: asmu1881@gmail.com
}

\begin{abstract}
Fossilization became a hot topic following Selinker's (1984) prediction that $95 \%$ of second language students would never gain native-like control of the chosen language. Although the exact causes are unknown, numerous experts have suggested that a lack of drive could be one of them. This study aims to know the role of motivation to overcome fossilization at SMAN 2 Tapung. The researcher believes that motivation has a big role to overcome fossilization in learning English as a foreign language. This study used descriptive qualitative research. The data were collected by using an open-ended questionnaire. Meanwhile, there are two participants in this research. The result showed that, students still have some difficulties in learning English and motivation also has a big role to overcome fossilization.
\end{abstract}

Keywords: Fossilization, Motivation, Pandemic Era

\section{Introduction}

Learning another language is a non-linear and fractured process characterized by a composite environment of explosive development in some regions and slowness of movement, implantation, or even a complete halt in others. As an outcome of this procedure, the term "interlanguage" was coined (Selinker, 1972) emerges, which approximates the target language to various degrees (TL). Interlanguage is symbolically a midway place between the first language (L1) and the target language (TL), thus the term "inter" (Selinker, 1972). L1 is said to be the mother language for the first construction elements, which are subsequently merged with components from the TL to produce new forms that are neither L1 nor T. Since Selinker (1972), there have been a variety of definitions (and concepts) of fossilization, as described in Han (2004). Nonetheless, they have generally addressed (i) recurrent deviance; (ii) resilience to external intervention; and (iii) to be out of the learner's influence. Additionally, almost, not all but, terms have emphasized a trend toward permanent partial or imperfect integration instead of a reality of permanent partial or incomplete acquisition.

According to Selinker, the great majority of second language (L2) students will never make it to the end of the interlanguage (IL) continuum, that is, they will never achieve native-like competencies in the target language (TL). No matter how old they are, or "the amount of explanation and training they received," they will most certainly "fossilize" a set of "linguistic elements, rules, and subsystems" (Selinker, 1972). When people are nervous, thrilled, or even incredibly relaxed, they "backslide," according to Selinker, making mistakes that were previously thought to have corrected (p. 36). He decided on the success rate for L2 students at 5\%, prompting academics to focus their attention on the unsuccessful 95\%. As Ellis points out, various Chomsky's and Lenneberg's theories of first language (L1) acquisition, have had a significant influence on fossilization.

In this pandemic era, teaching and learning process being hard to do. Teacher and students are doing teaching and learning process by using virtual learning. Of course, this condition is challenging for teachers. Students will lazy to study and also have lack of knowledge. In this case teacher have a big role to solve this problem. Teacher should improve students' motivation in teaching and learning process. 
Despite the fact that fossilization is still a prominent topic in the field of L2 acquisition, It appears to be based on speculation rather than proof.. In fact, in recent decades, the latter has piqued people's curiosity, as highly motivated people have been shown to produce greater results. Learning a new language necessitates dedication, which can be difficult to maintain when one is uninterested. "The motivated individual will demonstrate a strong desire to learn the language, and will endeavour to attain success," Gardner (2001) says (p. 6). The goal of this research is to look at fossilization from two perspectives: native speaker errors and motivational influences in the L2 learning process.

\section{The Definition of Fossilization}

Despite the significant academic effort given to it, fossilization is one of the most pervasive, yet least understood, phenomena in adult L2 learning (Moskovsky \& Ratcheva, 2014). Depending of the learner's grade or the amount of TL teaching he takes, fossilization is a procedure that underpinning surface language elements that learners will tend to retain in their IL productive performance (Wei, 2008). Despite the learner's good ability, opportunity, and motivation, Selinker and Lamendella (1978) characterized Fossilization is defined as a learner's irreversible halt of 1L learning before acquiring TL norms at all aspects of language structure and across all discourse domains, and motivation to learn and acculturate into target society (Wei, 2008).

\section{Classification of Fossilization}

a. Individual fossilization and group fossilization

Individual and group interlanguage fossilization, according to Selinker (1978), are the two types of interlanguage fossilization. Individual fossilization is usually divided into two categories: error reappearance and linguistic competency fossilization. Inappropriate interlanguage structures that are assumed to have been repaired but continue to occur on a regular basis are referred to as error recurrence. It can be discovered in the IL of beginners or low-skilled learners. The term "language competence fossilization" refers to a halt in the development of phonological, grammatical, lexical, and pragmatic competence in L2 learners. It is found in L2 learners who have been studying TL for a long time and have achieved a high degree of proficiency. In fact, competence fossilization is frequently demonstrated by recurrent blunders. Group fossilization occurs when fossilized language competency becomes widespread in a community. Such pervasiveness frequently results in the emergence of a new vernacular. Indian English and Singapore's English are two good examples.

b. Temporary fossilization and permanent fossilization

Selinker also divided fossilization into two categories: transient and permanent fossilization. Temporary fossilization, also known as stability, refers to learning plateaus "where the development of specific TL properties is simply 'arrested' or 'inhibited' for shorter or longer periods of time." As a result of social, psychological, and interactive aspects, permanent fossilization occurs.

\section{Types of Fossilization}

a. Phonological Fossilization

Phonological fossilization refers to the recurrence of phonological problems caused by improper L2 pronunciation, which is usually influenced by L1. There are several pronunciations in English that do not exist in Chinese, such as ". As a result, Chinese English learners find it difficult to pronounce the sound" correctly (Wei, 2008).

\section{b. Morphological Fossilization}

Because of the complexity of morphological modifications in English, there are several grammatical morphemes. The most prevalent issues are with the inflectional morpheme and the article. The suffixed third-person singular $-\mathrm{s}$ is suffixed to lexical verbs and auxiliaries such as has and is a component of 
syntactic agreement such as drinks. Buses, crises, and criteria, for example, are all identifiers for thirdperson singular (Wei, 2008).

\section{c. Syntactic Fossilization}

Different languages have their own syntactic rules. Of course, it will affect the learners in learning Second language. For Example, French L2 Learners. In French language they use SAVO and in English $\mathrm{SVO}$ is the correct one. Learners will use SAVO when they learn English as a second language.

d. Semantic Fossilization

The use of TL language forms that do not express the understandings that L2 learners want to express in the context is referred to as semantic fossilization (Wei, 2008).

\section{e. Pragmatic Fossilization}

The phrase "inability to understand what is intended by what is stated" describes pragmatic failure in cross-cultural communication. Misunderstanding, embarrassment, and even disrespect can arise from using inappropriate words (Wei, 2008).

\section{Causal Factors of Fossilization}

a. Language Transfer

Selinker (1972) believed that Some rules from the learner's L1 are transmitted to the learner's IL. Many faults in the use of L2 are caused by L1, and the difference between L1 and L2 is the source of the problems. As a result, the transfer of L1 rules can result in the formation of fossils. L1 can be transferred in either a positive or negative manner. Positive transfer means that the similarities shared by the L1 and L2 aid in the acquisition of the second language. Negative transfer, on the other hand, refers to disparities between L1 and L2 that obstruct second language acquisition. The influence of what has been previously learned arises in the context of and disrupts what is learned later in the negative transfer of L1, which behaviorists believe is proactive inhibition.

b. Training Transfer

One of the key causes of the fossilization of improper language forms, according to Graham (1981), is a lack of regular English training. "Learning just through interaction has led many pupils to construct IL or idiosyncratic languages with norms frequently dramatically different from those of Standard English," according to one study" (Wei, 2008).

c. Learning Strategy

The most typical reason of fossilization in the process of learning a second language is inappropriate application of learning methodologies. Sims (1989) proposed that "inappropriate or misapplied learning techniques could lead to fossilization of some characteristics somewhere along the IL continuum" (Wei, 2008).

\section{d. Overgeneralization}

Overgeneralization (Ellis, 2000) is the process of extending current L2 information to new IL forms. When people implicate a grammar to all students of a grammatical class without making the necessary exceptions, this happens. In fact, language overgeneralization always reflects a lack of understanding of rule limits, such as lexis or other linguistic objects' semantic restrictions. For example, the -ed suffix can be used to signify past tense for verbs such as "go" and "thought." 


\section{Central Issues}

Despite Selinker's assertions that he has multiple studies to back up his claims, just a few of them fit his own criteria. He set a somewhat arbitrary time limit of 2 to 5 years for error persistence to be accounted for as fossilization. Several experts, like Han (2004), have argued that this time frame is baseless, because, while the span varies from person to person, it should be based on "an average learner under optimal learning conditions" at the very least. Nonetheless, assuming its authenticity, Selinker's criterion is followed by only three investigations, none of which lasted more than two years. Others, on the other hand, are even more critical of the situation. For example, according to Jung (2002), in order to show that a structure is completely frozen and thus fossilized, one must examine "the learner's performance over a sufficient period of time, ideally from the moment of observation of a fossilized item until the learner's death" (cited in Han, 2004).

\section{Methods}

In this research the researcher was use descriptive qualitative research. Descriptive study aimed to reveal a wide range of qualitative approach by meticulously and nuancedly describing a thing, a condition, or a phenomenon; nevertheless, it is not limited to gather data; it also encompasses analysis and interpretation (Ary, Jacobs, Sorensen, \& Razavieh, 2010). The qualitative approach used in this research is based on a case study, which means that the qualitative study was used to identify the research emphasis in the form of a primary outcome measure that was appraised depending on the aim and addressed the author to the area of study before the author (Creswell, 2012). Data is essentially a raw material gathered by researchers all over the world (Sutopo, 2006: 85). The data in this research is the role of motivation to overcome fossilization in SMAN 2 Tapung. Sources of primary data in this study is the students of SMAN 2 Tapung. Our participant was consisting of two students at SMAN 2 TAPUNG, which is near researchers' house. The researcher identified the students who have characteristics that related to the topic. The data were collected from two students by using interviews. Following the collection of the relevant data, the researcher analyzes it using the coding procedure by Zacharias (2013), including data gathering, data classification, data display, and making conclusion.

\section{Results and Discussion}

The researcher uses the analysis data gathered from students through the use of a questionnaire instrument. The teachers were given the opportunity to communicate not only their problems and worries, but also their ideas and perceptions through the questionnaire. Questionnaire questions are divided into one segment by the researcher. The section distinguished grounded on the role of motivation to overcome fossilization; it is shown in the tables. The table presents the analysis result of the role of motivation to overcome fossilization. The result questionnaire of the role of motivation to overcome fossilization. The result from this research showed that; (1) there are several causes of difficulties in learning English, they are grammar, vocabulary, pronunciation, and listening, (2) motivation is the one of the big roles in overcome fossilization in learning second language.

The following table. Regarding the role of motivation to overcome fossilization at SMAN 2 Tapung. Questionnaires given to students about the difficulties and the importance of motivation in learning English as a foreign language.

Table 1. Results of Questionnaire

\begin{tabular}{|c|c|c|c|c|c|}
\hline \multirow[t]{2}{*}{ No. } & \multirow[t]{2}{*}{ Questions } & \multirow{2}{*}{\multicolumn{2}{|c|}{$\begin{array}{c}\text { Participant 1 } \\
\text { Answer }\end{array}$}} & \multirow{2}{*}{\multicolumn{2}{|c|}{$\frac{\text { Participant 1 }}{\text { Answer }}$}} \\
\hline & & & & & \\
\hline 1 & $\begin{array}{l}\text { There are some difficulties in learning } \\
\text { English. }\end{array}$ & $\underset{V}{\text { Yes }}$ & No & $\underset{V}{\text { Yes }}$ & No \\
\hline 2 & In learning English, one of the & $\sqrt{ }$ & & & $\sqrt{ }$ \\
\hline
\end{tabular}




\begin{tabular}{|c|c|c|c|c|c|}
\hline & difficulties is grammar. & & & & \\
\hline 3 & $\begin{array}{l}\text { In learning English, one of the } \\
\text { difficulties is vocabulary. }\end{array}$ & $\sqrt{ }$ & & $\sqrt{ }$ & \\
\hline 4 & $\begin{array}{l}\text { In learning English, the students } \\
\text { difficult to pronounce well. }\end{array}$ & $\sqrt{ }$ & & $\sqrt{ }$ & \\
\hline 5 & $\begin{array}{l}\text { In learning English, the students } \\
\text { difficult to understand what they have } \\
\text { listened. }\end{array}$ & $\sqrt{ }$ & & $\sqrt{ }$ & \\
\hline 6 & $\begin{array}{l}\text { Students are lazy to learn English } \\
\text { because there is no importance of } \\
\text { English for them }\end{array}$ & & $\sqrt{ }$ & $\sqrt{ }$ & \\
\hline 7 & $\begin{array}{l}\text { Students have less motivation in } \\
\text { learning English because English is } \\
\text { annoying and difficult to learn. }\end{array}$ & $\sqrt{ }$ & & $\sqrt{ }$ & \\
\hline 8 & $\begin{array}{l}\text { Students need the motivation to } \\
\text { overcome the difficulties in learning } \\
\text { English. }\end{array}$ & $\sqrt{ }$ & & $\sqrt{ }$ & \\
\hline 9 & $\begin{array}{l}\text { By giving the motivation students have } \\
\text { an intention to improve their ability in } \\
\text { English. }\end{array}$ & $\sqrt{ }$ & & $\sqrt{ }$ & \\
\hline 10 & $\begin{array}{l}\text { Motivation gives positive energy to the } \\
\text { students. }\end{array}$ & $\sqrt{ }$ & & $\sqrt{ }$ & \\
\hline & Total & 9 & 1 & 9 & 1 \\
\hline
\end{tabular}

Based on table on questionnaires given to students about the difficulties and importance of English are divided into some kind of statement that is associated with the role of motivation to overcome fossilization. There were ten statements given researcher to both students of SMAN 2 Tapung. Both participants provided different statements on points the second and sixth questioner statement, the second statement was "2) In learning English, one of the difficulties is grammar." The first participant stated grammar one of part that difficult to learn in English while the second participant stated grammar is not a difficult thing to learn. The sixth statement was "6) Students are lazy to learn English, because there is no importance of English for them". The first participant stated that laziness was a reason, but English still has an important while second participant stated that there was no importance of English as a reason of laziness in learning English as a foreign language. In the other statement two students have the same answer that answered "Yes" to all statements.

Based on the explanation can be concluded students have some difficulties and need a motivation to learn English as a foreign language. These findings initiate that it is important to give a motivation for EFL students, because this is something difficult for them. The existing findings in research on the role of motivation to overcome fossilization as follows:

a. Students still have difficulties in grammar, vocabulary, pronunciation, and listening.

b. Students still do not have a goal in learning English.

c. Students need a motivation in learning English as a foreign language.

As noted earlier, two student's language samples were collected by using ten statements of questionnaire, almost exactly about 20 minutes for students. The statements tested students' difficulties and the role of motivation in learning English. Researcher collect the data by sharing the questionnaires. The researchers translated the statement of questionnaire into Bahasa, in order the students can answer the question effectively. 


\section{Conclusion}

Based on the result, we can conclude that motivation plays an important role in the teaching and learning process, including in the ELT classroom. Although this research supports the notion that motivation is a true indicator of overcoming fossilization, research suggests that "fossilized learners" do not exist. For Indonesian learners, English, as a foreign language, of course, is a big challenge for students and teachers, especially in this pandemic era. It will be difficult for students to learn. Because of virtual classrooms they are not interested in learning English. In this case, teacher should motivate the students to learn. Teachers also can use an interesting method in the teaching and learning process.

Furthermore, many such strategies that can overcome fossilization can be learning strategy, watching native speakers' videos, so, students can follow how native speakers pronounce the word. By watching the video, also can improve students listening ability. However, in this case, students will be lazy to learn, if, they are not motivated to learn English, without knowing the goals, students will have a less intention, and also less interest in learning English. The teacher as a supervisor should give the students such a point of view or the idea. Like the importance of English for students, teachers can explain the benefit of English.

Finally, by conducting this research, we can see the different difficulties of English as a foreign language learner from another side. We are as EFL learners have to be aware of fossilization because this is also a big problem in learning English. Sometimes we already know the truth and are aware of the mistakes, but we still do the mistakes because of our mother tongue habits. Therefore, the researcher hope, this research can give benefit for the reader and also for future research related to motivation and fossilization.

\section{References}

Ary, D., Jacobs, L. C., Sorensen, C., \& Razavieh, A. (2010). Introduction to research education. Canada: Wadsworth.

Creswell, J. W. (2012). Educational research. Boston: Pearson.

Ellis, R. (2000). The study of second language acquisition. Shanghai: Shanghai Foreign Language Education Press.

Selinker, L. (1972). Interlanguage. IRAL, 10(2), 209-31.

Sutopo, H.B. 2006. Metodologi penelitian kualitatif, dasar teori dan terapannya dalam penelitian. Surakarta: Universitas Sebelas Maret Press.

Moskovsky, C., \& Ratcheva, S. (2014). L2 Fossilization: A competence or a performance phenomenon. The Open Communication Journal, 9-17.

Wei, X. (2008). The implication of IL fossilization in second language acquisition. English Language Teaching. 